

\title{
Efficacy of non-surgical treatments for androgenetic alopecia: a systematic review and network meta-analysis
}

\author{
Aditya K. Gupta M.D., Ph.D.1,2, Rachel R. Mays B.Sc. ${ }^{1}$, Michelle S. Dotzert Ph.D. ${ }^{1}$, Sarah G. Versteeg \\ M.Sc. ${ }^{1}$, Neil H. Shear M.D. ${ }^{2}$ and Vincent Piguet M.D. ${ }^{3}$ \\ ${ }^{1}$ Mediprobe Research Inc., London, Canada. \\ ${ }^{2}$ Department of Medicine, University of Toronto School of Medicine, Toronto, Canada. \\ ${ }^{3}$ Division of Infection and Immunity, Cardiff University School of Medicine, Cardiff, UK; Division of \\ Dermatology, Women's College Hospital, Toronto, Ontario, Canada; Division of Dermatology, \\ Department of Medicine, University of Toronto, Toronto, Ontario, Canada. \\ Running Head: Non-surgical treatments for Androgenetic Alopecia
}

\begin{abstract}
Androgenetic alopecia, or male/female pattern baldness, is the most common type of progressive hair loss disorder. The aim of this paper is to review recent advances in non-surgical treatments for androgenetic alopecia and identify the most effective treatments. A network meta-analysis (NMA) was conducted of the available literature of the six most common non-surgical treatment options for treating androgenetic alopecia in both men and women; dutasteride $0.5 \mathrm{mg}$, finasteride $1 \mathrm{mg}$, low level laser therapy (LLLT), minoxidil 2\%, minoxidil 5\% and platelet rich plasma (PRP). Seventy-eight studies met the inclusion criteria and twenty-two studies had the data necessary for a network meta-analysis. Relative effects show LLLT as the superior treatment. Relative effects show PRP, finasteride $1 \mathrm{mg}$ (male), finasteride $1 \mathrm{mg}$ (female), minoxidil $5 \%$, minoxidil $2 \%$ and dutasteride (male) are approximately equivalent in mean change hair count following treatment. Minoxidil $5 \%$ and minoxidil $2 \%$ reported the most drug-related adverse events ( $n=45$ and $n=23$, respectively). The quality of evidence of minoxidil $2 \%$ vs. minoxidil $5 \%$ was high; minoxidil $5 \%$ vs. placebo was moderate; dutasteride (male) vs. placebo, finasteride (female) vs placebo, minoxidil $2 \%$ vs. placebo, minoxidil $5 \%$ vs. LLLT was low and finasteride (male) vs. placebo, LLLT vs. sham, PRP vs. placebo, finasteride vs. minoxidil $2 \%$ was very low. Results of this NMA indicate the emergence of novel, non- hormonal therapies as effective treatments for hair loss; however, the quality of evidence is generally low. High quality randomized controlled trials and head to head trials are required to support these findings and aid in the development of more standardized protocols, particularly for PRP. Regardless, this analysis may aid physicians in clinical decision making and highlight the variety of non-surgical hair restoration options for patients.
\end{abstract}

\section{Summary}

Androgenetic alopecia (AGA) is a common hair loss condition that is characterized by the miniaturization of hair follicles in the frontal and parietal regions of the scalp ${ }^{1}$. This miniaturization may be driven by the conversion of testosterone to dihydrotestosterone (DHT) by 5- $\alpha$ reductase or alterations in the androgen receptor gene ${ }^{2-4}$. Treatments, such as hormone and biological response modifiers, have been used to combat this miniaturization and stabilize hair loss in AGA patients ${ }^{5,6}$. Hormone response modifiers, such as finasteride, promote hair growth by inhibiting type II 5- $\alpha$ reductase. This inhibition blocks the conversion of testosterone to $\mathrm{DHT}$, promoting cell survival and proliferation ${ }^{5,7}$. Although the exact mechanism for biological response modifiers, such as minoxidil, are not yet known, minoxidil is thought to promote hair growth through vasodilation and/or stimulation of hair follicles into the growth phase ${ }^{8-11}$. 
As an alternative to traditional therapies, other non-surgical treatments such as platelet-rich plasma (PRP) and low level laser therapy (LLLT) have also shown promise ${ }^{12}$. Through isolating platelets found in whole blood, growth factors can be concentrated and injected into the hair follicle and surrounding area. Evidence has suggested that these concentrated growth factors can promote angiogenesis and vascularization, accelerate hair regrowth, increase the duration of the hair growth phase and stimulate catagen development ${ }^{13-17}$. Alternatively, through photobiomodulation, red light emitted by LLLT devices may encourage hair growth by accelerating keratinocyte and fibroblast mitosis, inhibiting nitric oxide and reducing inflammation ${ }^{18-21}$ (Figure $1 \mathrm{a}, 1 \mathrm{~b}, 1 \mathrm{c}$ and $\left.1 \mathrm{~d}\right)$.

Due to the limited number of head-to-head clinical trials and the limitations of published meta-analyses (e.g., comparisons limited to 2 treatments), comparing the efficacies of non-surgical treatments is predominately qualitative ${ }^{22}$. Quantitative comparisons of the efficacy of non-surgical AGA treatments that have not been directly compared in head-to-head trials would be a valuable tool for both clinicians and hair restoration surgeons, potentially aiding treatment decisions and influencing patient outcomes. To address this literature gap a network meta-analysis was conducted using randomized control trials (RCTs) of six main non-surgical AGA treatments; finasteride, dutasteride, minoxidil (2\% and 5\%), PRP and LLLT. Using placebo as a common comparator, the efficacy of non-surgical treatments was indirectly and directly compared, using the mean difference in hair count from baseline as the outcome measure ${ }^{23}$.

\section{Materials and methods Systematic review}

This systematic review and meta-analysis was conducted in agreement with the 2015 modified 32 -item PRISMA extension statement for network meta-analysis (NMA) ${ }^{24}$. Studies were eligible for inclusion if they were randomized, placebo-controlled or head-to-head trials of non- surgical treatment for androgenetic alopecia published in English. Combination therapies were not included.

Details regarding the databases searched and study identification for this review are provided in Appendix S1 (see Supplementary Material). Treatment effects were evaluated based on the efficacy rates and safety parameters reported in the randomized trials identified during the systematic review. Hair count was selected as our primary outcome and the end point selected was the most commonly reported time per treatment regime (Table S1). Details regarding the quality of evidence and risk-of-bias assessment for this review are provided in Appendix $\mathrm{S}_{1}{ }^{25}$. Data extracted from trials were combined by a random-effects model, with effect sizes expressed as difference of means of achieving each outcome in the treatment arm versus the control arm. Total effect size was calculated by the Mantel-Haenszel method. Heterogeneity was evaluated with $P^{2}$ calculations. Statistical analysis was performed with RevMan 5.3 with two- tailed P-values $<0.05$ considered significant. Forest plots and funnel plots were obtained for each outcome analyzed and included in the supplementary material.

\section{Network meta-analysis}

NMA was used to make mixed comparisons among the therapeutic options and to rank treatments, using the program Aggregate Data Drug Information Software (ADDIS) version 1.16 .8 program ${ }^{26}$. Inconsistency between direct and indirect evidence in the network was analyzed using difference of means. A P-value < 0.05 indicated significant inconsistency between the direct and indirect evidence in the network. 


\section{Results}

\section{Results of the search}

There were 10,484 records identified by our literature search (PubMed, Scopus, Embase, Cochrane Libraries, ClinicalTrials.gov and Medline) (Figure 2). Seventy-eight ${ }^{27-45,45-48,17,49-103}$ met the inclusion criteria and were included in the quantitative analysis. A total of 15,888 participants $(88.1 \%$ male) were included with an average age $36.0 \pm 7.3$ (Table 1).

Twenty-two studies ${ }^{28,32,37,45,46,48,52,61,64,65,68,69,72,80,85,84,81,93,98,101-103}$ of the seventy-eight included in the quantitative analysis had the data necessary for a network meta-analysis. The included trials had 2,421 randomized participants, which were $64.2 \%$ male. The average age of participants was $37.7 \pm 7.1$. The severity of disease was most commonly IV $(n=273)$ and III vertex $(n=497)$ on the Norwood-Hamilton Classification and II $(n=381)$ on the Ludwig/Savin Scale. Detailed information for all the studies included in the network meta-analysis is presented in Table 1. A network graph summarizing the comparisons is provided in Figure 3.

\section{Risk of bias}

None of the included studies were judged to be low-risk across all six domains (Figure S1). With the exception of one domain (selective reporting), Hillmann et al. ${ }^{52}$, was the only study to have a low-risk judgement across all domains. Four studies ${ }^{64,65,69,72}(20 \%)$ were judged as low-risk on all but two domains. Detection bias (blinding of the outcome assessment) had the lowest risk of bias (64\% of papers reported low risk). Incomplete outcome data (attrition bias - not reporting all participants and/or reasons for discontinuation) was the domain with the largest number of studies (50\%) to be judged as high-risk, followed closely by selective reporting (reporting bias) (27\%). Price et al. ${ }^{84}$, was the only study to have an unclear judgement across all domains.

\section{Quality of evidence}

When considering mean hair count, evidence for treatment efficacy was generally low quality according to GRADEpro assessment. In treatment versus placebo studies: LLLT, PRP and finasteride (male) reported very low quality of evidence, finasteride (female), dutasteride (male) and minoxidil $2 \%$ had low quality evidence and minoxidil $5 \%$ had moderate quality evidence. When considering the treatment versus treatment: finasteride (male) versus minoxidil $2 \%$ had very low level quality of evidence, minoxidil $5 \%$ versus LLLT had low level of evidence and minoxidil $2 \%$ versus minoxidil $5 \%$ had high quality of evidence. Evidence was downgraded initially due to high risk of bias. Additionally, LLLT studies showed considerable inconsistency with high heterogeneity $\left(\mathrm{I}^{2}=93 \%\right)$. Dutasteride (male), LLLT, PRP, finasteride (male) vs minoxidil $2 \%$, and minoxidil $5 \%$ vs LLLT analyzed less than 400 participants which contributed to the imprecision of the evidence.

\section{Efficacy of direct comparisons}

Meta-analysis of direct pair-wise comparisons showed that all non-surgical treatments exhibited greater efficacy over placebo with response to mean change hair count (Table 2, Figure S2). LLLT was the most effective treatment (mean difference [95\% Cl]: 66.70 [24.09, 109.31]), followed by PRP (23.51 [9.91, 37.11]) as demonstrated by their mean change hair count. Finasteride (female) was the least effective treatment $(-1.93[-5.27,1.42])$. Minoxidil $5 \%$ had the most drug- related adverse events $(n=45)$ whereas PRP had the least $(n=0)$, Table 1 and 5. Direct comparisons of treatments showed that finasteride was favoured over minoxidil $2 \%(8.10$ [3.80, 12.40], minoxidil $5 \%$ was favoured over minoxidil $2 \%$ (4.69 [1.35, 8.04]) and LLLT was favoured over minoxidil 5\% (1.53 [22.64, 25.70]) (Table 2, Figure S2-S5). 
Results of the network meta-analysis indicate that the mean difference of LLLT is superior to all treatments. Additionally, finasteride (male) and minoxidil $2 \%$ indicated greater efficacy over placebo $(21.140$ [7.454, 35.465] and 16.615 [1.885, 33.023]) (Table 3). Otherwise relative effects showed that PRP, finasteride (male), finasteride (female), minoxidil $5 \%$, minoxidil $2 \%$ and dutasteride (male) are approximately equivalent in mean change hair count following treatment (Table 3 ).

\section{Inconsistency analysis}

The indirect comparison of minoxidil $5 \%$ vs placebo, minoxidil $5 \%$ vs minoxidil $2 \%$, minoxidil $5 \%$ vs LLLT and finasteride (male) vs placebo showed a treatment effect larger than the direct evidence. The indirect comparisons of minoxidil $2 \%$ vs placebo, LLLT vs sham and minoxidil $2 \%$ vs finasteride (male), showed a treatment effect smaller than the direct evidence (Table 4).

\section{Model Fit}

The mean deviance under the current model, relative to the deviance under a saturated model is referred to as the residual deviance. The residual deviance of our model was 50.5, the leverage (the influence of each data point) was 42.8 and the Deviance Information Criterion (model fit versus model complexity) was 93.3. The number of data points on which the fit is based was 46 (Figure S6).

\section{Ranking of treatments by efficacy}

Rank probabilities encode the probability for each treatment to be the best, second best, third best, etc. The probability that LLLT will be the most effective treatment option (rank 1) for our data is $92 \%$, followed by PRP (5.2\%). The probability that PRP will be the second most effective treatment option (rank 2) is $33.8 \%$, followed by minoxidil $5 \%(21.8 \%)$. The probability that finasteride (male) will be the third most effective treatment option is $29.3 \%$, and so on (Figure 4 ).

We used the surface under the cumulative ranking (SUCRA) probabilities to assess the efficacy of treatments. SUCRA expresses a percentage representing the efficacy of every intervention compared with a control. It is used to provide a hierarchy of the treatments and accounts both for the location and the variance of all relative treatment effects. A higher SUCRA score indicates a higher probability to be effective. The SUCRA scores demonstrate LLLT with the highest SUCRA (98.7\%) followed by PRP, finasteride (male) and minoxidil 5\% with similar scores (64.3\%, 62.5\% and 62.4\%; respectively). Minoxidil 2\%, dutasteride (male) and finasteride (female) report lower scores $(51.0 \%, 32.9 \%$ and $14.4 \%$; respectively) (Table 5).

\section{Discussion}

This network meta-analysis (NMA) compared the relative efficacy of finasteride, minoxidil $2 \%$ and $5 \%$, low level laser therapy and platelet-rich plasma therapy in the treatment of androgenetic alopecia. Results indicate that the mean difference of LLLT is greater compared to all treatments. Additionally relative effects show PRP, finasteride $1 \mathrm{mg}$, minoxidil $5 \%$, minoxidil $2 \%$ and dutasteride are approximately equivalent in mean change hair count following treatment. Minoxidil $5 \%$ and $2 \%$ reported the greatest amount of adverse events.

While results of this NMA indicate LLLT produced the largest increase in hair count, the quality of evidence is very low as determined by the risk of bias assessment. Further, these trials may require further scrutiny, as all five trials included in the NMA report funding and support from the device manufacturer or funding and/or affiliation of the author with the manufacturer. Nonetheless, these trials met the strict inclusion criteria of this NMA and analysis indicates LLLT is a highly effective treatment option. 
PRP is also an effective treatment for AGA. However, quality of evidence of PRP is "very low" according to GRADEpro assessment. There are few randomized controlled trials examining the efficacy of PRP in AGA. Half head studies are common in the literature, however, this design may be considered problematic as each patient contributes to the treatment and control arm of the study. There is also a high degree of variability in study design among PRP trials. Studies have reported treatment administration weekly, monthly, and bimonthly and range in the total number of treatment sessions. Further, unlike oral or topical formulations such as finasteride or minoxidil, which are prescribed at standard doses, there is significant variability in the preparation and administration of PRP. Individual preparation systems and added activators can influence the concentration of growth factors ${ }^{17}$. Coupled to variability in frequency and volume of injections, this creates substantial differences in dosing across studies. We included trials in which activated PRP was administered.

Finasteride $1 \mathrm{mg}$ and minoxidil 5\% demonstrated similar efficacy. As such, other factors including the risk of adverse events (AEs) may contribute to clinical decision making. AEs reported with finasteride use are predominantly related to sexual dysfunction. Decreased libido, erectile dysfunction, and sexual adverse events are reported in several of the trials included in this NMA. The prevalence of sexual adverse events associated with finasteride use is widely discussed in the literature. We have previously demonstrated an increase in reports of sexual dysfunction with finasteride as the primary suspect in the U.S. Food and Drug Administration Adverse Event Reporting System (FAERS) ${ }^{104}$. Others report persistent sexual dysfunction up to one year after cessation of finasteride treatment ${ }^{105}$. The side effects of minoxidil 5\% ranged from dermatologic in nature, such as hypertrichosis, and burning and itching of the skin, to cardiovascular AEs. The mechanism of action of minoxidil may contribute to the cardiovascular AEs, as it is a vasodilator. While the results of this NMA indicate finasteride $1 \mathrm{mg}$ and minoxidil 5\% demonstrate similar efficacy, considering the AEs associated with each treatment may aid in clinical decision making.

We included data for male and female participants from trials for minoxidil, LLLT and PRP. However, we separated the males and females for finasteride and dutasteride as we felt the results would have been skewed if we combined them. There were no studies reporting females taking dutasteride. In AGA, dihydrotestosterone (DHT) binding to androgen receptors in the scalp contributes to hair loss. DHT is formed by enzymatic conversion of testosterone to DHT by $5 \alpha$ - reductase, and these enzymes are inhibited by finasteride and dutasteride. Given the hormonal mechanism of action of $5 \alpha$-reductase inhibitors, they are not approved for the treatment of hair loss in female patients. Finasteride has been associated with negative effects on the fetus as well as menstrual and endometrial abnormalities among others $^{106}$. Dutasteride is a dual $5 \alpha$-reductase inhibitor, which is approved for use in the treatment of benign prostatic hyperplasia and is used off- label for hair loss. Therefore, data for female participants was separated from the males.

A potential limitation of this analysis was the use of hair count as a primary outcome measure. AGA treatment efficacy can be determined with a variety of different assessments. Expert assessment of global photographs, hair counts using phototrichogram and manual hair counts using clippings have all been reported in the literature. Our rationale for selecting hair count was twofold: first, this is a more quantitative measure than global photographic assessment; studies reporting only global photographic assessment were not included. Second, some studies reported hair density (the number of hairs per predefined area). It is possible to convert hair count to hair density when provided a target area, however it is not possible if the area is not specified. Therefore, in order to maximize the number of included trials 
in this NMA we selected hair count as our primary outcome measure. Unfortunately, this may be a limiting factor, as larger target areas would in theory have greater hair counts. This presents a point of consideration in the development and initiation of new trials. The use of a consistent outcome measure may aid in the comparison of treatment efficacy across many different treatments for hair loss or other dermatological conditions.

Another limitation to this study is the comparison of drugs with different routes of administration. Oral (finasteride), topical (LLLT, minoxidil) and intradermal injection (PRP) were all compared in this NMA. These treatments function through unique mechanisms of action and may have different metabolism and durations of effect. Despite this, all treatments compared in this analysis are FDA approved for use in the treatment of AGA. Therefore, these findings are relevant to clinicians and patients in the development of a treatment plan.

In addition to these limitations, the measurement of efficacy for AGA treatments has not yet been standardized; leading to multiple units of analysis reported across studies and therapies (e.g. hair density, hair count, hair shedding etc.). Furthermore, of the 20 studies included in the analysis, only six $(30 \%)$ did not have obvious links to industry ${ }^{28,38,45,80,93,102}$. Most studies included in the analysis $(14 / 20=$ $70 \%$ ) were supported or funded by invested parties (e.g., drug manufacture, patent owner, etc.). This may have contributed to the high number of studies judged to have a high risk of reporting bias and/or attrition bias. Industry funding for studies is often inevitable and appreciated; high-quality trials with low risk of bias counters perceptions of conflicted interests.

Systematic reviews as well as clinical trials must be designed rigorously in order to ensure the validity of the finding of the network meta-analysis. Interpreting the results of a NMA can prove challenging for the non-expert statistician. One of the most commonly misinterpreted parts of a NMA is the probability rankings. Ranking done in medical statistics will always depend on the criteria; one treatment may be best for efficacy but worse for long term safety. A risk subsists that one may incorrectly accentuate the probabilities as being clinically useful. That is why it is important to consider the numerical values of the rankings themselves, not only their probability ranks. The SUCRA scores also can be misleading as the SUCRA is most meaningful when the difference in preference between successive ranks remains the same across the entire ranking scale ${ }^{107}$. Our data does not have such interval scaling, thus weakening the SUCRA evidence. For clinical application, greater emphasis on the treatment effects and their uncertainty are crucial. As new trials are published, the network will expand and treatment rankings may change considerably. Consideration should also be issued to cost and a clinician's familiarity with use of a particular treatment.

In summary, results of this NMA indicate the emergence of more novel, non-hormonal therapies as effective treatments for hair loss. Further randomized controlled trials and head to head trials limiting risk of bias are required to support these findings and aid in the development of more standardized protocols, particularly for PRP. The data may provide guidance to physicians when counselling patients with AGA regarding non-surgical options. 


\section{References}

1. Hoffmann R. Male androgenetic alopecia. Clin Exp Dermatol. 2002 Jul;27(5):373-82.

2. Sawaya ME, Price VH. Different levels of 5alpha-reductase type I and II, aromatase, and androgen receptor in hair follicles of women and men with androgenetic alopecia. J Invest Dermatol. 1997 Sep;109(3):296-300.

3. Schweikert H, Wilson J. Regulation of human hair growth by steroid hormones. II. Androstenedione metabolism in isolated hairs. J Clin Endocrinol Metab. 1974;39(6):1012-9.

4. Levy-Nissenbaum E, Bar-Natan M, Frydman M, Pras E. Confirmation of the association between male pattern baldness and the androgen receptor gene. Eur J Dermatol EJD. 2005 Oct;15(5):339-40.

5. PROPECIA® (finasteride) tablets for oral use [Internet]. Drugs@FDA: FDA Approved Drug Products. 2014 [cited 2017 Dec 21]:

https://www.accessdata.fda.gov/scripts/cder/daf/index.cfm?event=overview.process\&AppINo =020788

6. Johnson and Johnson Inc. Rogaine (minoxidil) Product Monograph. 2011.

7. Gupta A, Carveil J. A Mechanistic Model of Platelet-Rich Plasma Treatment for Androgenetic Alopecia. Dermatol Surg. 2016;42(12):1335-9.

8. Messenger AG, Rundegren J. Minoxidil: mechanisms of action on hair growth. $\mathrm{Br} \mathrm{J}$ Dermatol. 2004 Feb;150(2):186-94.

9. Lachgar S, Moukadiri H, Jonca F, Charveron M, Bouhaddioui N, Gall Y, et al. Vascular endothelial growth factor is an autocrine growth factor for hair dermal papilla cells. J Invest Dermatol. 1996 Jan;106(1):17-23.

10. Michelet JF, Commo S, Billoni N, Mahé YF, Bernard BA. Activation of cytoprotective prostaglandin synthase- 1 by minoxidil as a possible explanation for its hair growth-stimulating effect. J Invest Dermatol. 1997 Feb;108(2):205-9.

11. HAIR REGROWTH FORMULA Minoxidil Topical Solution USP $20 \mathrm{mg} / \mathrm{mL}$ ( $2 \% \mathrm{w} / \mathrm{v}$ ) [Internet]. Government of Canada. 2011. Available from: https://pdf.hres.ca/dpd_pm/00033538.PDF

12. Gupta AK, Carviel JL. Meta-analysis of efficacy of platelet-rich plasma therapy for androgenetic alopecia. J Dermatol Treat. 2017 Feb;28(1):55-8.

13. Heldin $\mathrm{CH}$, Westermark $\mathrm{B}$. Mechanism of action and in vivo role of platelet-derived growth factor. Physiol Rev. 1999 Oct;79(4):1283-316.

14. Stenn KS, Paus R. Controls of Hair Follicle Cycling. Physiol Rev. 2001 Jan 1;81(1):449-94.

15. Yano K, Brown LF, Detmar M. Control of hair growth and follicle size by VEGF-mediated angiogenesis. J Clin Invest. 2001 Feb;107(4):409-17.

16. Li J, Yang Z, Li Z, Gu L, Wang Y, Sung C. Exogenous IGF-1 promotes hair growth by stimulating cell proliferation and down regulating TGF- $\beta 1$ in C57BL/6 mice in vivo. Growth Horm IGF Res Off J Growth Horm Res Soc Int IGF Res Soc. 2014 Jun;24(2-3):89-94.

17. Gentile P, Cole JP, Cole MA, Garcovich S, Bielli A, Scioli MG, et al. Evaluation of Not-Activated and Activated PRP in Hair Loss Treatment: Role of Growth Factor and Cytokine Concentrations Obtained by Different Collection Systems. Int J Mol Sci. 2017 Feb 14;18(2).

18. Lubart $\mathrm{R}$, Eichler M, Lavi R, Friedman $\mathrm{H}$, Shainberg A. Low-energy laser irradiation promotes cellular redox activity. Photomed Laser Surg. 2005 Feb;23(1):3-9. 
19. Eells JT, Wong-Riley MTT, VerHoeve J, Henry M, Buchman EV, Kane MP, et al. Mitochondrial signal transduction in accelerated wound and retinal healing by near-infrared light therapy. Mitochondrion. 2004 Sep;4(5-6):559-67.

20. Sakurai Y, Yamaguchi M, Abiko Y. Inhibitory effect of low-level laser irradiation on LPS- stimulated prostaglandin E2 production and cyclooxygenase-2 in human gingival fibroblasts. Eur J Oral Sci. 2000 Feb;108(1):29-34.

21. Darwin E, Heyes A, Hirt PA, Wikramanayake TC, Jimenez JJ. Low-level laser therapy for the treatment of androgenic alopecia: a review. Lasers Med Sci. 2017 Dec 21;

22. Adil A, Godwin M. The effectiveness of treatments for androgenetic alopecia: A systematic review and meta-analysis. J Am Acad Dermatol. 2017 Jul;77(1):136-141.e5.

23. Jansen JP, Fleurence R, Devine B, Itzler R, Barrett A, Hawkins N, et al. Interpreting indirect treatment comparisons and network meta-analysis for health-care decision making: report of the ISPOR Task Force on Indirect Treatment Comparisons Good Research Practices: part 1. Value Health J Int Soc Pharmacoeconomics Outcomes Res. 2011 Jun;14(4):417-28.

24. Hutton B, Salanti G, Caldwell DM, Chaimani A, Schmid CH, Cameron C, et al. The PRISMA extension statement for reporting of systematic reviews incorporating network meta-analyses of health care interventions: checklist and explanations. Ann Intern Med. 2015 Jun 2;162(11):777-84.

25. Assessing Risk of Bias in Included Studies | Cochrane Bias [Internet]. [cited 2017 Dec 28]. Available from: /bias/assessing-risk-bias-included-studies

26. van Valkenhoef G, Tervonen T, Zwinkels T, de Brock B, Hillege H. ADDIS: a decision support system for evidence-based medicine [Internet]. 2012 [cited 2012 Aug 29]. Available from: http://drugis.org/files/addisdss.pdf

27. Abell E. Histologic response to topically applied minoxidil in male-pattern alopecia. Clin Dermatol. 1988 Dec;6(4):191-4.

28. Alves R, Grimalt R. Randomized Placebo-Controlled, Double-Blind, Half-Head Study to Assess the Efficacy of Platelet-Rich Plasma on the Treatment of Androgenetic Alopecia. Dermatol Surg Off Publ Am Soc Dermatol Surg Al. 2016 Apr;42(4):491-7.

29. Anderson C. Topical Minoxidil in Androgenetic Alopecia Scandinavian and Middle East Experience. Int J Dermatol. 1988 Aug;27(s6):447-451.

30. Arca E, Taştan HB, Akar A, Kurumlu Z, Gür AR. An open, randomized, comparative study of oral fluconazole, itraconazole and terbinafine therapy in onychomycosis. J Dermatol Treat. 2002 Mar;13(1):3-9.

31. Bao L, Gong L, Guo M, Liu T, Shi A, Zong H, et al. Randomized trial of electrodynamic microneedle combined with $5 \%$ minoxidil topical solution for the treatment of Chinese male Androgenetic alopecia. J Cosmet Laser Ther Off Publ Eur Soc Laser Dermatol. 2017 Oct 13;

32. Barikbin B, Khodamrdi Z, Kholoosi L, Akhgri MR, Haj Abbasi M, Hajabbasi M, et al. Comparison of the effects of $665 \mathrm{~nm}$ low level diode Laser Hat versus and a combination of $665 \mathrm{~nm}$ and 808nm low level diode Laser Scanner of hair growth in androgenic alopecia. J Cosmet Laser Ther Off Publ Eur Soc Laser Dermatol. 2017 May 17;

33. Bergfeld W, Washenik K, Callender V, Zhang P, Quiza C, Doshi U, et al. A Phase III, Multicenter, ParallelDesign Clinical Trial to Compare the Efficacy and Safety of 5\% Minoxidil Foam Versus Vehicle in Women With Female Pattern Hair Loss. J Drugs Dermatol JDD. 2016 Jul 1;15(7):874- 81. 
34. Blume-Peytavi U, Kunte C, Krisp A, Garcia Bartels N, Ellwanger U, Hoffmann R. Comparison of the efficacy and safety of topical minoxidil and topical alfatradiol in the treatment of androgenetic alopecia in women. $J$ Dtsch Dermatol Ges J Ger Soc Dermatol JDDG. 2007 May;5(5):391-5.

35. Brenner S, Matz H. Improvement in androgenetic alopecia in 53-76-year-old men using oral finasteride. Int J Dermatol. 1999 Dec;38(12):928-30.

36. Carmina E, Lobo RA. Treatment of hyperandrogenic alopecia in women. Fertil Steril. 2003 Jan;79(1):915.

37. Cervelli V, Garcovich S, Bielli A, Cervelli G, Curcio BC, Scioli MG, et al. The effect of autologous activated platelet rich plasma (AA-PRP) injection on pattern hair loss: clinical and histomorphometric evaluation. BioMed Res Int. 2014;2014:760709.

38. Civatte J, Laux B, Simpson NB, Vickers CF. $2 \%$ topical minoxidil solution in male-pattern baldness: preliminary European results. Dermatologica. 1987;175 Suppl 2:42-9.

39. Connors T j., Cooke D e., Launey WED, Downie M, Knudsen R g., Shumack S, et al. Australian Trial of Topical Minoxidil and Placebo in Early Male Pattern Baldness. Australas J Dermatol. 1990;31(1):17-25.

40. De Villez RL. Topical minoxidil therapy in hereditary androgenetic alopecia. Arch Dermatol. 1985 Feb;121(2):197-202.

41. De Villez RL. Androgenetic alopecia treated with topical minoxidil. J Am Acad Dermatol. $1987 \mathrm{Mar} ; 16$ (3 Pt 2):669-72.

42. DeVillez RL, Jacobs JP, Szpunar CA, Warner ML. Androgenetic alopecia in the female. Treatment with $2 \%$ topical minoxidil solution. Arch Dermatol. 1994 Mar;130(3):303-7.

43. Dhurat R, Chitallia J, May TW, Jayaraaman AM, Madhukara J, Anandan S, et al. An Open-Label Randomized Multicenter Study Assessing the Noninferiority of a Caffeine-Based Topical Liquid $0.2 \%$ versus Minoxidil 5\% Solution in Male Androgenetic Alopecia. Skin Pharmacol Physiol. 2017 Oct 21;30(6):298-305.

44. Dutrée-Meulenberg ROGM, Nieboer C, Koedijk FHJ, Stolz E. Treatment of Male Pattern Alopecia Using Topical Minoxidil in The Netherlands. Int J Dermatol. 1988 Jul 1;27:435-40.

45. Esmat SM, Hegazy RA, Gawdat HI, Abdel Hay RM, Allam RS, El Naggar R, et al. Low level light- minoxidil $5 \%$ combination versus either therapeutic modality alone in management of female patterned hair loss: $A$ randomized controlled study. Lasers Surg Med. 2017 Nov;49(9):835-43.

46. Eun HC, Kwon OS, Yeon JH, Shin HS, Kim BY, Ro BI, et al. Efficacy, safety, and tolerability of dutasteride $0.5 \mathrm{mg}$ once daily in male patients with male pattern hair loss: a randomized, double-blind, placebo-controlled, phase III study. J Am Acad Dermatol. 2010 Aug;63(2):252-8.

47. Faghihi G, Iraji F, Rajaee Harandi M, Nilforoushzadeh M-A, Askari G. Comparison of the efficacy of topical minoxidil $5 \%$ and adenosine $0.75 \%$ solutions on male androgenetic alopecia and measuring patient satisfaction rate. Acta Dermatovenerol Croat ADC. 2013;21(3):155-9.

48. Friedman S, Schnoor P. Novel Approach to Treating Androgenetic Alopecia in Females With Photobiomodulation (Low-Level Laser Therapy). Dermatol Surg Off Publ Am Soc Dermatol Surg Al. 2017 Jun;43(6):856-67.

49. Gentile P, Garcovich S, Bielli A, Scioli MG, Orlandi A, Cervelli V. The Effect of Platelet-Rich Plasma in Hair Regrowth: A Randomized Placebo-Controlled Trial. Stem Cells Transl Med. 2015 Nov;4(11):1317-23.

50. Gubelin Harcha W, Barboza Martínez J, Tsai T-F, Katsuoka K, Kawashima M, Tsuboi R, et al. A randomized, active- and placebo-controlled study of the efficacy and safety of different doses of dutasteride 
versus placebo and finasteride in the treatment of male subjects with androgenetic alopecia. J Am Acad Dermatol. 2014 Mar;70(3):489-498.e3.

51. Hajheydari Z, Akbari J, Saeedi M, Shokoohi L. Comparing the therapeutic effects of finasteride gel and tablet in treatment of the androgenetic alopecia. Indian J Dermatol Venereol Leprol. 2009 Feb;75(1):47-51.

52. Hillmann K, Garcia Bartels N, Kottner J, Stroux A, Canfield D, Blume-Peytavi U. A Single-Centre, Randomized, Double-Blind, Placebo-Controlled Clinical Trial to Investigate the Efficacy and Safety of Minoxidil Topical Foam in Frontotemporal and Vertex Androgenetic Alopecia in Men. Skin Pharmacol Physiol. 2015;28(5):236-44.

53. Hu R, Xu F, Sheng Y, Qi S, Han Y, Miao Y, et al. Combined treatment with oral finasteride and topical minoxidil in male androgenetic alopecia: a randomized and comparative study in Chinese patients. Dermatol Ther. 2015 Oct;28(5):303-8.

54. Jacobs JP, Szpunar CA, Warner ML. Use of topical minoxidil therapy for androgenetic alopecia in women. Int J Dermatol. 1993 Oct;32(10):758-62.

55. Jimenez JJ, Wikramanayake TC, Bergfeld W, Hordinsky M, Hickman JG, Hamblin MR, et al. Efficacy and safety of a low-level laser device in the treatment of male and female pattern hair loss: a multicenter, randomized, sham device-controlled, double-blind study. Am J Clin Dermatol. 2014 Apr;15(2):115-27.

56. Katz HI, Hien NT, Prawer SE, Goldman SJ. Long-term efficacy of topical minoxidil in male pattern baldness. J Am Acad Dermatol. 1987 Mar;16(3 Pt 2):711-8.

57. Kaufman KD, Olsen EA, Whiting D, Savin R, DeVillez R, Bergfeld W, et al. Finasteride in the treatment of men with androgenetic alopecia. Finasteride Male Pattern Hair Loss Study Group. J Am Acad Dermatol. 1998 Oct;39(4 Pt 1):578-89.

58. Finasteride Male Pattern Hair Loss Study Group. Long-term (5-year) multinational experience with finasteride $1 \mathrm{mg}$ in the treatment of men with androgenetic alopecia. Eur J Dermatol EJD. 2002 Feb;12(1):3849.

59. Kawashima M, Hayashi N, Igarashi A, Kitahara H, Maeguchi M, Mizuno A, et al. Finasteride in the treatment of Japanese men with male pattern hair loss. Eur J Dermatol EJD. 2004 Aug;14(4):247-54.

60. Khandpur S, Suman M, Reddy BS. Comparative efficacy of various treatment regimens for androgenetic alopecia in men. J Dermatol. 2002;29(8):489-98.

61. Kim H, Choi JW, Kim JY, Shin JW, Lee S-J, Huh C-H. Low-level light therapy for androgenetic alopecia: a 24-week, randomized, double-blind, sham device-controlled multicenter trial. Dermatol Surg Off Publ Am Soc Dermatol Surg Al. 2013 Aug;39(8):1177-83.

62. Koperski JA, Orenberg EK, Wilkinson DI. Topical minoxidil therapy for androgenetic alopecia. A 30-month study. Arch Dermatol. 1987 Nov;123(11):1483-7.

63. Kreindler TG. Topical minoxidil in early androgenetic alopecia. J Am Acad Dermatol. 1987 Mar;16(3 Pt 2):718-24.

64. Lanzafame RJ, Blanche RR, Bodian AB, Chiacchierini RP, Fernandez-Obregon A, Kazmirek ER. The growth of human scalp hair mediated by visible red light laser and LED sources in males. Lasers Surg Med. 2013 Oct;45(8):487-95.

65. Lanzafame RJ, Blanche RR, Chiacchierini RP, Kazmirek ER, Sklar JA. The growth of human scalp hair in females using visible red light laser and LED sources. Lasers Surg Med. 2014 Oct;46(8):601-7. 
66. Leavitt M, Charles G, Heyman E, Michaels D. HairMax LaserComb laser phototherapy device in the treatment of male androgenetic alopecia: A randomized, double-blind, sham device- controlled, multicentre trial. Clin Drug Investig. 2009;29(5):283-92.

67. Leenen FH, Smith DL, Unger WP. Topical minoxidil: cardiac effects in bald man. Br J Clin Pharmacol. 1988 Oct;26(4):481-5.

68. Leyden J, Dunlap F, Miller B, Winters P, Lebwohl M, Hecker D, et al. Finasteride in the treatment of men with frontal male pattern hair loss. J Am Acad Dermatol. 1999 Jun;40(6 Pt 1):930-7.

69. Lucky AW, Piacquadio DJ, Ditre CM, Dunlap F, Kantor I, Pandya AG, et al. A randomized, placebocontrolled trial of $5 \%$ and $2 \%$ topical minoxidil solutions in the treatment of female pattern hair loss. J Am Acad Dermatol. 2004 Apr;50(4):541-53.

70. Mapar MA, Shahriari S, Haghighizadeh MH. Efficacy of platelet-rich plasma in the treatment of androgenetic (male-patterned) alopecia: A pilot randomized controlled trial. J Cosmet Laser Ther Off Publ Eur Soc Laser Dermatol. 2016 Dec;18(8):452-5.

71. Olsen EA, DeLong ER, Weiner MS. Dose-response study of topical minoxidil in male pattern baldness. J Am Acad Dermatol. 1986 Jul;15(1):30-7.

72. Olsen EA, Dunlap FE, Funicella T, Koperski JA, Swinehart JM, Tschen EH, et al. A randomized clinical trial of $5 \%$ topical minoxidil versus $2 \%$ topical minoxidil and placebo in the treatment of androgenetic alopecia in men. J Am Acad Dermatol. 2002 Sep;47(3):377-85.

73. Olsen EA, Hordinsky M, Whiting D, Stough D, Hobbs S, Ellis ML, et al. The importance of dual 5a-reductase inhibition in the treatment of male pattern hair loss: Results of a randomized placebo-controlled study of dutasteride versus finasteride. J Am Acad Dermatol. 2006 Dec;55(6):1014-23.

74. Olsen EA, Whiting D, Bergfeld W, Miller J, Hordinsky M, Wanser R, et al. A multicenter, randomized, placebo-controlled, double-blind clinical trial of a novel formulation of $5 \%$ minoxidil topical foam versus placebo in the treatment of androgenetic alopecia in men. J Am Acad Dermatol. 2007 Nov;57(5):767-74.

75. Olsen EA, Whiting DA, Savin R, Rodgers A, Johnson-Levonas AO, Round E, et al. Global photographic assessment of men aged 18 to 60 years with male pattern hair loss receiving finasteride $1 \mathrm{mg}$ or placebo. J Am Acad Dermatol. 2012 Sep;67(3):379-86.

76. Panahi Y, Taghizadeh M, Marzony ET, Sahebkar A. Rosemary oil vs minoxidil $2 \%$ for the treatment of androgenetic alopecia: a randomized comparative trial. Skinmed. 2015 Feb;13(1):15-21.

77. Pazoki-Toroudi H, Babakoohi S, Nilforoushzadeh MA, Nassiri-Kashani M, Shizarpour M, Ajami M, et al. Therapeutic effects of minoxidil high extra combination therapy in patients with androgenetic alopecia. Skinmed. 2012 Oct;10(5):276-82.

78. Petzoldt D, German topical Minoxidil Study Group. The German Double-Blind Placebo- Controlled Evaluation of Topical Minoxidil Solution in the Treatment of Early Male Pattern Baldness. Int J Dermatol. 1988 Aug;27(s6):430-434.

79. Piepkorn MW, Weidner M. Comparable efficacy of $2 \%$ minoxidil gel and solution formulations in the treatment of male pattern alopecia. J Am Acad Dermatol. 1988 May;18(5 Pt 1):1059-62.

80. Prasad HR, Khanna N, Pandhi RK. A randomized double blind study of the effect of finasteride on hair growth in male patients of androgenetic alopecia. Indian J Dermatol. 2005 Jul 1;50(3):139.

81. Price VH, Menefee E. Quantitative estimation of hair growth. I. androgenetic alopecia in women: effect of minoxidil. J Invest Dermatol. 1990 Dec;95(6):683-7. 
82. Price VH, Menefee E, Strauss PC. Changes in hair weight and hair count in men with androgenetic alopecia, after application of 5\% and 2\% topical minoxidil, placebo, or no treatment. J Am Acad Dermatol. 1999 Nov;41(5 Pt 1):717-21.

83. Price VH, Menefee E, Sanchez M, Kaufman KD. Changes in hair weight in men with androgenetic alopecia after treatment with finasteride (1 mg daily): Three- and 4-year results. J Am Acad Dermatol. 2006;55(1):71-4.

84. Price VH, Menefee E, Sanchez M, Ruane P, Kaufman KD. Changes in hair weight and hair count in men with androgenetic alopecia after treatment with finasteride, $1 \mathrm{mg}$, daily. J Am Acad Dermatol. 2002 Apr;46(4):517-23.

85. Price VH, Roberts JL, Hordinsky M, Olsen EA, Savin R, Bergfeld W, et al. Lack of efficacy of finasteride in postmenopausal women with androgenetic alopecia. J Am Acad Dermatol. 2000 Nov;43(5 Pt 1):768-76.

86. Puig CJ, Reese R, Peters M. Double-Blind, Placebo-Controlled Pilot Study on the Use of Platelet- Rich Plasma in Women With Female Androgenetic Alopecia. Dermatol Surg Off Publ Am Soc Dermatol Surg Al. 2016 Nov;42(11):1243-7.

87. Rietschel RL, Duncan SH. Safety and efficacy of topical minoxidil in the management of androgenetic alopecia. J Am Acad Dermatol. 1987 Mar;16(3 Pt 2):677-85.

88. Roberts JL. Androgenetic alopecia: treatment results with topical minoxidil. J Am Acad Dermatol. 1987 Mar;16(3 Pt 2):705-10.

89. Roberts JL, Fiedler V, Imperato-McGinley J, Whiting D, Olsen E, Shupack J, et al. Clinical dose ranging studies with finasteride, a type 2 5alpha-reductase inhibitor, in men with male pattern hair loss. J Am Acad Dermatol. 1999 Oct;41(4):555-63.

90. Rossi A, Mari E, Scarno M, Garelli V, Maxia C, Scali E, et al. Comparitive effectiveness of finasteride vs Serenoa repens in male androgenetic alopecia: a two-year study. Int J Immunopathol Pharmacol. 2012 Dec;25(4):1167-73.

91. Rushton DH, Unger WP, Cotterill PC, Kingsley P, James KC. Quantitative assessment of $2 \%$ topical minoxidil in the treatment of male pattern baldness. Clin Exp Dermatol. 1989 Jan;14(1):40-6.

92. Sakr FM, Gado AM, Mohammed HR, Adam ANI. Preparation and evaluation of a multimodal minoxidil microemulsion versus minoxidil alone in the treatment of androgenic alopecia of mixed etiology: a pilot study. Drug Des Devel Ther. 2013;7:413-23.

93. Saraswat A, Kumar B. Minoxidil vs finasteride in the treatment of men with androgenetic alopecia. Arch Dermatol. 2003 Sep;139(9):1219-21.

94. Savin RC. Use of topical minoxidil in the treatment of male pattern baldness. J Am Acad Dermatol. 1987 Mar;16(3 Pt 2):696-704.

95. Shanshanwal SJS, Dhurat RS. Superiority of dutasteride over finasteride in hair regrowth and reversal of miniaturization in men with androgenetic alopecia: A randomized controlled open- label, evaluator-blinded study. Indian J Dermatol Venereol Leprol. 2017 Feb;83(1):47-54.

96. Shupack JL, Kassimir JJ, Thirumoorthy T, Reed ML, Jondreau L. Dose-response study of topical minoxidil in male pattern alopecia. J Am Acad Dermatol. 1987 Mar;16(3 Pt 2):673-6.

97. Spindler JR. The safety of topical minoxidil solution in the treatment of pattern baldness: the results of a 27-center trial. Clin Dermatol. 1988 Dec;6(4):200-12.

98. Stough DB, Rao NA, Kaufman KD, Mitchell C. Finasteride improves male pattern hair loss in a randomized study in identical twins. Eur J Dermatol EJD. 2002 Feb;12(1):32-7. 
99. Stough D. Dutasteride improves male pattern hair loss in a randomized study in identical twins. J Cosmet Dermatol. 2007 Mar;6(1):9-13.

100. Tawfik AA, Osman MAR. The effect of autologous activated platelet-rich plasma injection on female pattern hair loss: A randomized placebo-controlled study. J Cosmet Dermatol. 2017 May 14;

101. Van Neste D, Fuh V, Sanchez-Pedreno P, Lopez-Bran E, Wolff $H$, Whiting D, et al. Finasteride increases anagen hair in men with androgenetic alopecia. Br J Dermatol. 2000 Oct;143(4):804- 10.

102. Whiting DA, Jacobson C. Treatment of female androgenetic alopecia with minoxidil $2 \%$. Int J Dermatol. 1992 Nov;31(11):800-4.

103. Whiting DA, Waldstreicher J, Sanchez M, Kaufman KD. Measuring reversal of hair miniaturization in androgenetic alopecia by follicular counts in horizontal sections of serial scalp biopsies: results of finasteride 1 mg treatment of men and postmenopausal women. J Investig Dermatol Symp Proc. 1999 Dec;4(3):282-4.

104. Gupta AK, Carviel J, MacLeod MA, Shear N. Assessing finasteride-associated sexual dysfunction using the FAERS database. J Eur Acad Dermatol Venereol JEADV. 2017 Jun;31(6):1069-75.

105. Guo M, Heran B, Flannigan R, Kezouh A, Etminan M. Persistent Sexual Dysfunction with Finasteride 1 mg Taken for Hair Loss. Pharmacotherapy. 2016 Nov;36(11):1180-4.

106. Wu M, Yu Q, Li Q. Differences in reproductive toxicology between alopecia drugs: an analysis on adverse events among female and male cases. Oncotarget. 2016 Oct 12;7(50):82074-84.

107. Salanti G, Ades AE, loannidis JPA. Graphical methods and numerical summaries for presenting results from multiple-treatment meta-analysis: an overview and tutorial. J Clin Epidemiol. 2011 Feb;64(2):163-71. 
Table 1 Studies included in the network meta-analysis for non-surgican treatment sfor AGA

\begin{tabular}{|c|c|c|c|c|c|c|c|c|c|}
\hline Author & Agont & Doses & $\begin{array}{l}\text { Nat } \\
\text { randonization }\end{array}$ & $\begin{array}{l}\text { Wole } \\
\text { (B) }\end{array}$ & $\begin{array}{l}\text { Ludnolo } \\
\text { Srvin } \\
\text { Scale (n) }\end{array}$ & 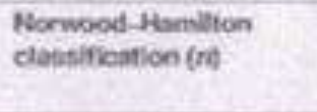 & $\begin{array}{l}\text { Ago } \\
\text { Wean }=\text { SO } \\
\text { prange) }\end{array}$ & $\begin{array}{l}\text { Houn changos } \\
\text { halr count } \\
\text { thoon } 1 \text { So }\end{array}$ & 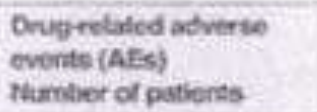 \\
\hline \multicolumn{10}{|c|}{ Dutanteride ve, placebo in w 15 \}) } \\
\hline \multirow[t]{2}{*}{$\underset{2010^{\circ}}{\operatorname{Ein}}=$} & Duatsondse & $0.5 \mathrm{mg}$ & 1593 & 100 & $\mathrm{Na}$ & Eivinor 38 N 14 V.21 & $32=7,1$ & $122+236$ & 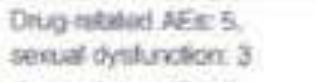 \\
\hline & Placebo & & & & & E & $384=66$ & $47+168$ & 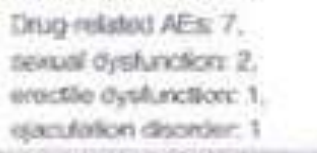 \\
\hline \multicolumn{10}{|c|}{ Finiesteride ve. placobo $(a=976)$} \\
\hline \multirow[t]{2}{*}{$\begin{array}{l}\text { toysten of al } \\
\text { rocipe }\end{array}$} & Frobstedos & $10 \mathrm{reg}$ & 326 & 100 & Na & 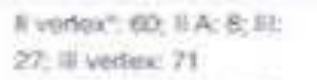 & $320+52$ & $26+10.32$ & 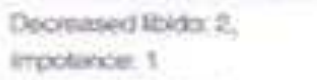 \\
\hline & Plocobs & & & & & 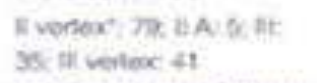 & $320=3.1$ & $-2.06=1897$ & 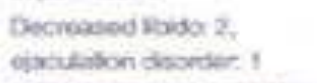 \\
\hline \multirow[t]{2}{*}{$\begin{array}{l}\text { Prasat or at } \\
2005^{\circ}\end{array}$} & Frovatede & $1.0 \mathrm{mg}$ & es & 100 & Na: & 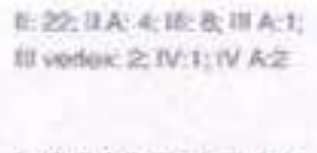 & $245=28$ & $20.56+20.02$ & 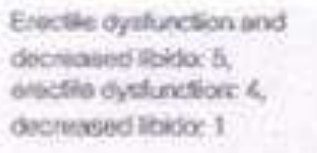 \\
\hline & Pracubo & & & & & 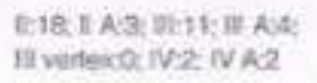 & $240 \pm 25$ & $-956 \geq 3697$ & \\
\hline $\begin{array}{l}\text { Phive of a } \\
\text { 200\%" }\end{array}$ & $\begin{array}{l}\text { Frusteso: } \\
\text { Procetor }\end{array}$ & $10 \mathrm{mg}$ & 60 & 900 & & tea:At:A & I2: +46 & $\begin{array}{l}x+12=25.51 \\
7.01=13.90\end{array}$ & 0. \\
\hline 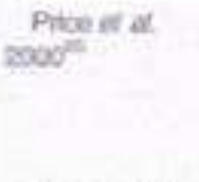 & $\begin{array}{l}\text { Firasiloto } \\
\text { Parcebs }\end{array}$ & $30 \mathrm{me}$ & 197 & 0 . & $\begin{array}{l}122: 11: 65 \\
t 31: \neq 39\end{array}$ & Na & $\begin{array}{l}53=4 \\
53=5\end{array}$ & $\begin{array}{l}-5.7 \geq 2644 \\
-6.6 \pm 2604\end{array}$ & 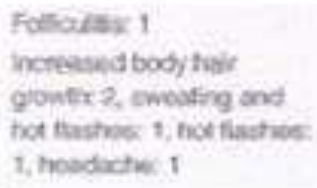 \\
\hline \multirow[t]{2}{*}{$\begin{array}{l}\text { staugh ef al } \\
\text { zooten }\end{array}$} & Firvatebdy & to no & 15 & 100 & NA & 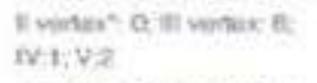 & $39.8=25$ & $16=11.37$ & 0 \\
\hline & Faceto & & & & & 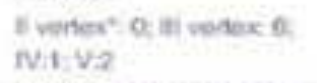 & $396 \times 23$ & $-4=15$ & \\
\hline \multirow[t]{2}{*}{$\begin{array}{l}\text { Varinester } \\
\text { of } 2.2000^{\circ}=0\end{array}$} & Prustarid & 2000 & 212 & 100 & NA & 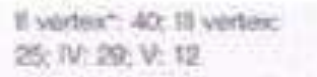 & $302=62$ & $72+1089$ & \\
\hline & Plicoto & & & & & $\begin{array}{l}\text { Eventex; as is vertex } \\
\text { as: iv is: Vis }\end{array}$ & $28.3=62$ & $-101=38.81$ & Sexual sherbs event: 1 \\
\hline \multirow{2}{*}{$\begin{array}{l}\text { Whating et at } \\
150 p^{\circ}\end{array}$} & Finsteovas & $10 \mathrm{mg}$ & 137 & 0 & Mo. & 10 & $\mid k 1-60\}$ & $-19=1: 3$ & 0 \\
\hline & Plissebs & & & & & & & $0.0 \pm 13$ & \\
\hline
\end{tabular}

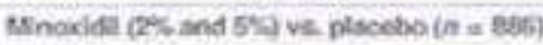

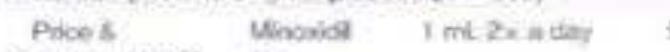

Menctes, toon" 75

Placesos

$\mid-2$ is: 0
vidis

NeA

(22. 41)

$3675 \pm 246$ 


\begin{tabular}{|c|c|c|c|c|c|c|c|c|c|}
\hline Author: & Agont & Dose & $\begin{array}{l}\text { Nat } \\
\text { randorriaation }\end{array}$ & $\begin{array}{l}\text { Mtate } \\
\text { (c) }\end{array}$ & 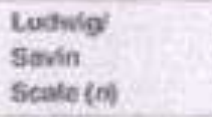 & $\begin{array}{l}\text { Norwood flamilon } \\
\text { clatsification (m) }\end{array}$ & $\begin{array}{l}\text { Age } \\
\text { than } \leqslant 50 \text {. } \\
\text { (Range) }\end{array}$ & $\begin{array}{l}\text { Bown change } \\
\text { halr cocint } \\
\text { Mean = So }\end{array}$ & $\begin{array}{l}\text { Drugrelaled abverea: } \\
\text { evisuts (AEs) } \\
\text { Number of patients }\end{array}$ \\
\hline \multirow{2}{*}{$\begin{array}{l}\text { Whings: } \\
\text { Jasobson } \\
\text { toggio }\end{array}$} & $\begin{array}{l}\text { Mencoide } \\
2 \pi\end{array}$ & 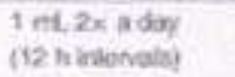 & 30 & 0 & $k: 13, v: 4$ & NA & $340,(22-44)$ & $28 \pm 29$ & 0 \\
\hline & Pacebo & & & & $1: 9.6: 7$ & & $340,(23,44)$ & $20 \pm 18$ & \\
\hline \multirow[t]{3}{*}{$\begin{array}{l}\text { Lucty at at } \\
\text { s000" }\end{array}$} & $\begin{array}{l}\text { Hrowde } \\
\text { 2tis }\end{array}$ & 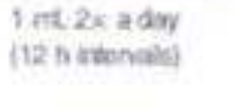 & 301 & 0. & $k 86,0: 50,12: 2$ & & 37.0 & 2072.176 & 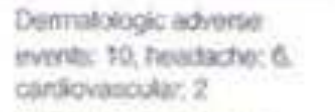 \\
\hline & $\begin{array}{l}\text { Mnoidd } \\
5 \pi\end{array}$ & & & & 1.56.11:28, $\pm=6$ & Nh & अ० & $245=21.9$ & 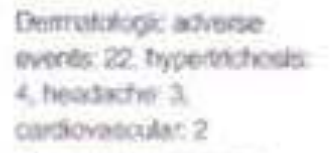 \\
\hline & Plasebo & & & & $t 27, \pi, 4, \pi, 3:$ & & 37.0 & $9.4=148$ & 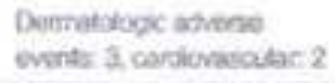 \\
\hline \multirow[t]{3}{*}{$\begin{array}{l}\text { Oxen ar all } \\
\text { 2000" }\end{array}$} & $\begin{array}{l}\text { Mrnonda } \\
2 \%\end{array}$ & 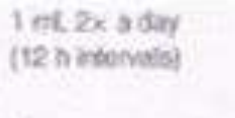 & 303 & 100 & NA & 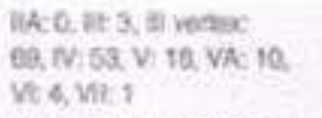 & $30.5 \neq 0.5$ & $12.7 \pm 20.7$ & 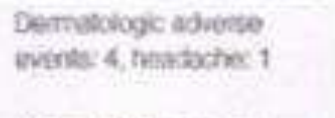 \\
\hline & $\begin{array}{l}\text { Menond: } \\
5 \text { th: }\end{array}$ & & & & & 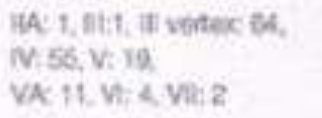 & $262+6.4$ & $186 \pm 284$ & 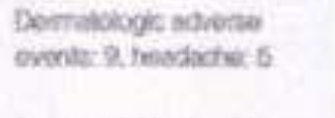 \\
\hline & Plocento & & & & & 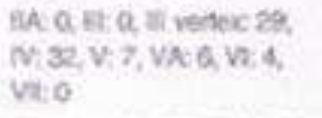 & $368 \pm 6.4$ & $39 \pm 217$ & $\begin{array}{l}\text { Demsilolopic advese } \\
\text { evernts: 2, Aendacter } 1 .\end{array}$ \\
\hline \multirow[t]{2}{*}{$\begin{array}{l}\text { Hamanom al } \\
\text { 2015" }\end{array}$} & $\begin{array}{l}\text { Fincaide: } \\
\text { ste }\end{array}$ & reasiui $2 x$ aday & $\pi$ & 100 & NA & 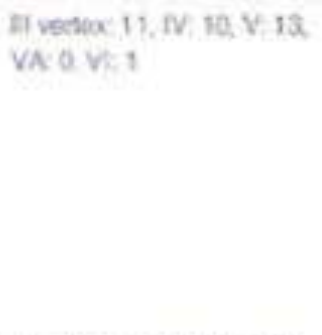 & $432=122$ & $73 \pm 241$ & 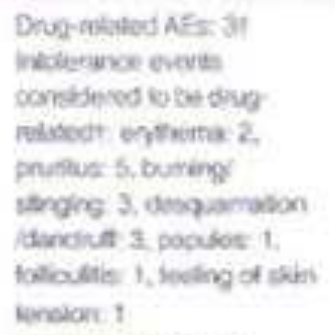 \\
\hline & Pasobo & & & & BLA & 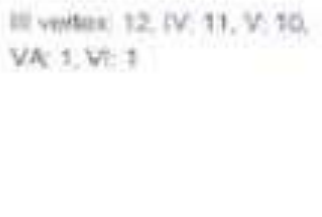 & $23,8=11,4$ & $-15=150$ & 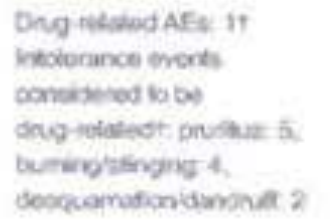 \\
\hline
\end{tabular}




\begin{tabular}{|c|c|c|c|c|c|c|c|c|c|}
\hline Author: & Agent & Dose & $\begin{array}{l}\text { Nat } \\
\text { randomization }\end{array}$ & $\begin{array}{l}\text { licole } \\
\text { (es) }\end{array}$ & $\begin{array}{l}\text { Lubuig' } \\
\text { Stwin } \\
\text { Scale (r) }\end{array}$ & $\begin{array}{l}\text { Noritood-Hanition } \\
\text { classitioution (o) }\end{array}$ & $\begin{array}{l}\text { Age } \\
\text { toom } \neq 50 \text {, } \\
\text { (Rings) }\end{array}$ & $\begin{array}{l}\text { Move chango } \\
\text { balr oount } \\
\text { Ecoun } \pm \text { So }\end{array}$ & $\begin{array}{l}\text { Drup-eisted adverse } \\
\text { ovents (AEs) } \\
\text { Mumber of patlents }\end{array}$ \\
\hline \multicolumn{10}{|c|}{ Low-tevel laser therapy vas, plscobo $(a=242)$} \\
\hline \multirow[t]{3}{*}{$\begin{array}{l}\text { Earthin ef at. } \\
2017^{2}\end{array}$} & 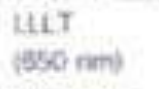 & $\begin{array}{l}3 \text { firres a wovkt } \\
\text { for } 4 \text { northe }\end{array}$ & 30 & 67 & 2.3. it: int: & 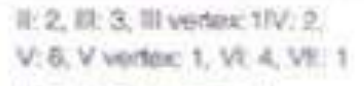 & $\operatorname{sos}=1401$ & $16.13=10.44$ & \\
\hline & $\begin{array}{l}\text { ULT } 6050 \\
-809-\mathrm{mm} t\end{array}$ & & 30 & & to, 01,31$\}$ & 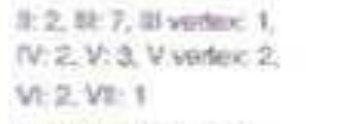 & $9057=1675$ & $0.00=85$ & 0 \\
\hline & Starn & & 30 & & 10 & $\begin{array}{l}n: 3,0: 6, N: 1, v: 7 \\
v=1, n: 2\end{array}$ & $35+10=14: 36$ & $-12=2.15$ & \\
\hline Fisedrien 8 . & UT & 30 ath every & 49 & $\theta$ & 대, 14 & Nes & $48.4+53$ & $69.00=633 t$ & 0 \\
\hline Bchnoos, 2010" & Stras & otwerday & & & E:13, a: 9 & & $47.1 \pm 11.6$ & $1852+2648$ & \\
\hline \multirow{2}{*}{$\begin{array}{l}\text { Kimet at: } \\
201 z^{\prime \prime}\end{array}$} & UHT & 28 minctiry. & 29 & 52 & Es. $1: 1$ & at: 6 iv $2, V:$, V: 5 & $439 \div 122$ & $120.40=85 i 08$ & $\theta$ \\
\hline & Shar & & & & $1: 8$ & 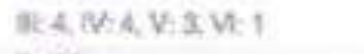 & $44.5=11.4$ & $-15=126.10$ & \\
\hline \multirow{2}{*}{$\begin{array}{l}\text { Larvalame } \\
\text { of at } 2013 \text { is }\end{array}$} & Щт & 25 min enery & 41 & 100 & & ila-V & $(13-45)$ & $86.64=45.20$ & 0 \\
\hline & Ghare & & & & & & $(18-49)$ & $1463=5320$ & \\
\hline \multirow{2}{*}{$\begin{array}{l}\text { Larualame } \\
\text { of } 2014^{\circ}\end{array}$} & utt & 25 min every & 42 & o. & 27,111 & Na & $463+82$ & $100.33=53.30$ & 0 \\
\hline & Shart & cenerday & & & $1: 11,12: 13$ & & $51: 0 \pm 7.7$ & $23.92=30.12$ & \\
\hline \multicolumn{10}{|c|}{ Plasclet rich plesma is placeto in = 39) } \\
\hline \multirow[t]{2}{*}{$\begin{array}{l}\text { Cened ef at } \\
\text { 2014" }\end{array}$} & $\begin{array}{l}\text { PhP } \\
\text { (actrovisod) }\end{array}$ & $\begin{array}{l}3 \text { wersions at } \\
30 \text { dry ktengas }\end{array}$ & 10 & 100 & wh & SAW & $327=1057$ & $27 \geq 15.3$ & 0 \\
\hline & Paspoo & & & & & & & $-21=124$ & \\
\hline \multirow[t]{2}{*}{$\begin{array}{l}\text { Alves } 8 \\
\text { Grimel. } 2016^{25}\end{array}$} & $\begin{array}{l}\text { PFP } \\
\text { (Astingled) }\end{array}$ & $\begin{array}{l}3 \text { serssions af } \\
\text { 9y-divy intorvals }\end{array}$ & 25 & 48 & NA & HN & $39124 \tan$ & $12.8 \div 22.8$ & 0 \\
\hline & Pacebo & & & & & & & $-21=31.3$ & \\
\hline \multicolumn{10}{|c|}{ Mincaide 25 ve, thateride $(n=99)$} \\
\hline \multirow[t]{2}{*}{$\begin{array}{l}\text { Simasats } \\
\text { Kuma, 2008? }\end{array}$} & $\begin{array}{l}\text { Mroids } \\
8 x\end{array}$ & $10 t 2 x a d y$ & 9 & 100 & NA & 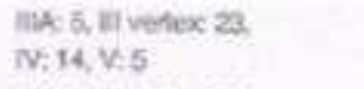 & $2 \pi 7234$ & $9.6 \pm 6.04$ & 9 \\
\hline & Finastesde & 109 & & & & 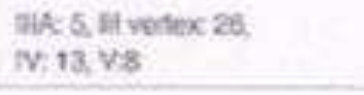 & $290 \pm 43$ & $17.7 \pm 14$ & 0 \\
\hline \multicolumn{10}{|c|}{ Minoaidii S) vs. LUT $(n=30)$} \\
\hline \multirow[t]{2}{*}{$\begin{array}{l}\text { Eemat of at? } \\
2017 \text { ? }\end{array}$} & $\begin{array}{l}\text { Mhowide } \\
\text { this }\end{array}$ & Tulcediny & IS & 0 & Le, it: $6,17 k \cdot$ & NA & $3927=5.57$ & $18.08=3.54$ & 0 \\
\hline & utT & $\begin{array}{l}25 \text { min every } \\
3 \text { days }\end{array}$ & 25 & & te2, in, $10, \mathrm{nt} 3$ & & $35.67 \pm 7.37$ & $202 \pm 6.36$ & \\
\hline
\end{tabular}

* Rating based on a modified version of the Norwood-Hamilton classification scale tUnit of analysis: number of adverse events 
Table 2 Direct comparison of each non-surgical treatment included in the network

\begin{tabular}{|c|c|c|c|}
\hline Treatment 1 & Treatment 2 & $\frac{\text { Mean change hair }}{\text { count }}$ & $\frac{\text { Number of trials making }}{\text { direct comparison }}$ \\
\hline \multicolumn{4}{|c|}{ Treatment vs. Placebo } \\
\hline LLLT & Placebo & $66.70[24.26,109.13]$ & 5 \\
\hline PRP & Placebo & $23.51[9.91,37.11]$ & 2 \\
\hline Finasteride $1 \mathrm{mg}$ (male) & Placebo & $17.37[11.67,23.07]$ & 5 \\
\hline Minoxidil 5\% & Placebo & $14.24[10.72,17.75]$ & 3 \\
\hline Minoxidil 2\% & Placebo & $11.51[5.34,17.67]$ & 4 \\
\hline Dutasteride $0.5 \mathrm{mg}$ (male) & Placebo & $7.50[0.76,14.24]$ & 1 \\
\hline Finasteride 1 mg (female) & Placebo & $-1.93[-5.27,1.42]$ & 2 \\
\hline \multicolumn{4}{|c|}{ Treatment vs. Treatment } \\
\hline Finasteride $1 \mathrm{mg}$ (male) & Minoxidil 2\% & $8.10[3.80,12.40]$ & 1 \\
\hline Minoxidil 2\% & Minoxidil 5\% & $4.69[1.35,8.04]$ & 2 \\
\hline Minoxidil 5\% & LLLT & $1.53[-22.64,25.70]$ & 1 \\
\hline
\end{tabular}


Table 3. Relative effects table. Comparison of the included interventions: mean difference ( $95 \%$ Credible intervals). Each cell gives the effect of the column-defining intervention relative to the row-defining intervention.

\begin{tabular}{|c|c|c|c|c|c|c|c|}
\hline 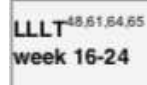 & $\begin{array}{l}-25.317 \\
(-49.628,-4.692)\end{array}$ & $\begin{array}{l}-46.642 \\
(-67.444,-29.365)\end{array}$ & $\begin{array}{l}-25.184 \\
(-50.989,-4.318)\end{array}$ & $\begin{array}{l}-29.729 \\
(-55.303,-8.590)\end{array}$ & $\begin{array}{l}-23.790 \\
(-57.495,5.807)\end{array}$ & $\begin{array}{l}-48.270 \\
(-81.057,-21.108)\end{array}$ & $\begin{array}{l}-38.930 \\
(-80.913,-4.799)\end{array}$ \\
\hline & $\begin{array}{l}\text { Minoxidil } 5 \%^{52, e \theta, 72} \\
\text { week } 24-48\end{array}$ & $\begin{array}{l}-20.912 \\
(-39.152,-5.233)\end{array}$ & $\begin{array}{l}0.187 \\
(-21.937,20.564)\end{array}$ & $\begin{array}{l}-4.204 \\
(-23.957,14.404)\end{array}$ & $\begin{array}{l}1.777 \\
(-30.053,30.773)\end{array}$ & $\begin{array}{l}-22.682 \\
(-52.705,5.631)\end{array}$ & $\begin{array}{l}-13.924 \\
(-51.536,22.640)\end{array}$ \\
\hline & & 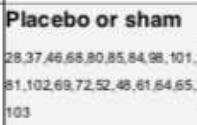 & $\begin{array}{l}21.140 \\
(7.454,35.465)\end{array}$ & $\begin{array}{l}16.615 \\
(1.885,33.023)\end{array}$ & $\begin{array}{l}22.794 \\
(-2.165,48.520)\end{array}$ & $\begin{array}{l}-1.891 \\
(-25.046,21.287)\end{array}$ & $\begin{array}{l}7.380 \\
(-25.890,39.535)\end{array}$ \\
\hline & & & $\begin{array}{l}\text { Finasteride } 1 \mathrm{mg} \\
\text { (male) } \\
(59,80,8493,98,101 \\
\text { week 14-26 }\end{array}$ & $\begin{array}{l}-4.415 \\
(-22.822,14.910)\end{array}$ & $\begin{array}{l}1.740 \\
(-28.043,30.343)\end{array}$ & $\begin{array}{l}-22.927 \\
(-50.120,3.679)\end{array}$ & $\begin{array}{l}-13.741 \\
(-50.404,20.258)\end{array}$ \\
\hline & & & & $\begin{array}{l}\text { Minoxidil } \\
2 \%{ }^{67.72,31.93,102} \\
\text { week 32-52 }\end{array}$ & $\begin{array}{l}6.211 \\
(-23.988,35.338)\end{array}$ & $\begin{array}{l}-18.508 \\
(-46.960,8.961)\end{array}$ & $\begin{array}{l}-9.341 \\
(-47.301,25.836)\end{array}$ \\
\hline & & & & & $\begin{array}{l}\text { PRP }^{28.37} \\
\text { week 14-26 }\end{array}$ & $\begin{array}{l}-24.772 \\
(-59.363,9.575)\end{array}$ & $\begin{array}{l}-15.516 \\
(-57.572,25.393)\end{array}$ \\
\hline & & & & & & $\begin{array}{l}\text { Finasteride } 1 \mathrm{mg} \\
\text { (female) } \\
\text { week } 52\end{array}$ & $\begin{array}{l}9.090 \\
(-32.980,48.968)\end{array}$ \\
\hline & & & & & & & $\begin{array}{l}\text { Dutasteride } 0.5 \mathrm{mg} \\
\text { (male) } \\
\text { week } 26\end{array}$ \\
\hline
\end{tabular}


Table 4. Results from the node-splitting analysis of consistency/inconsistency comparisons.

\begin{tabular}{|c|c|c|c|c|c|c|}
\hline Treatment 1 & Treatment 2 & Direct estimate & Indirect estimate & $\begin{array}{l}\text { Random effects } \\
\text { standard deviation }\end{array}$ & $\begin{array}{l}\text { Inconsistency } \\
\text { P-value }\end{array}$ & DIC $^{b}$ \\
\hline Minoxidil 5\% & Placebo & $\begin{array}{l}-15.516 \\
(-37.865,7.362)\end{array}$ & $\begin{array}{l}-53.150 \\
(-105.110,-5.456)\end{array}$ & $\begin{array}{l}17.499 \\
(10.752,30.459)\end{array}$ & 0.155 & 87.2 \\
\hline Minoxidil $2 \%$ & Placebo & $\begin{array}{l}17.572 \\
(-3.533,39.387)\end{array}$ & $\begin{array}{l}12.568 \\
(-32.362,58.046)\end{array}$ & $\begin{array}{l}18.613 \\
(10.941,32.629)\end{array}$ & 0.829 & 88.0 \\
\hline Minoxidil 5\% & Minoxidil $2 \%$ & $\begin{array}{l}-4.341 \\
(-33.730,24.290)\end{array}$ & $\begin{array}{l}-6.740 \\
(-50.813,32.868)\end{array}$ & $\begin{array}{l}18.633 \\
(10.920,32.716)\end{array}$ & 0.913 & 88.5 \\
\hline Minoxidil 5\% & LLLT & $\begin{array}{l}-1.479 \\
(-42.992,38.260)\end{array}$ & $\begin{array}{l}-35.792 \\
(-66.252,-10.702)\end{array}$ & $\begin{array}{l}15.544 \\
(9.517,26.274)\end{array}$ & 0.144 & 91.6 \\
\hline LLLT & Sham & $\begin{array}{l}-52.419 \\
(-75.594,-33.765)\end{array}$ & $\begin{array}{l}-17.838 \\
(-63.381,27.334)\end{array}$ & $\begin{array}{l}15.465 \\
(9.535,26.203)\end{array}$ & 0.142 & 91.7 \\
\hline $\begin{array}{l}\text { Finasteride } 1 \mathrm{mg} \\
\text { (male) }\end{array}$ & Placebo & $\begin{array}{l}20.291 \\
(3.874,37.067)\end{array}$ & $\begin{array}{l}26.275 \\
(-11.929,67.835\end{array}$ & $\begin{array}{l}16.185 \\
(9.588,27.988)\end{array}$ & 0.752 & 92.6 \\
\hline Minoxidil $2 \%$ & $\begin{array}{l}\text { Finasteride } 1 \mathrm{mg} \\
\text { (male) }\end{array}$ & $\begin{array}{l}-8.254 \\
(-43.057,26.829)\end{array}$ & $\begin{array}{l}-2.256 \\
(-25.948,22.639)\end{array}$ & $\begin{array}{l}16.054 \\
(9.454,27.989)\end{array}$ & 0.760 & 92.9 \\
\hline
\end{tabular}

A $p$ value $<.05$ indicated significant inconsistency between the direct and indirect evidence in the network

The p-value measures consistency by calculating the probability of observing the results from your sample of data or a sample with results more extreme, assuming the null hypothesis is true. The smaller the p-value, the greater the inconsistency

'The deviance information criterion (DIC), is a measure of model fit that penalizes model complexity. The DIC is used to compare fit between models for the same data; differences in DIC of 3 or greater are often considered relevant. 
Table 5. Ranking of competing non-surgical treatments for AGA.

\begin{tabular}{|l|l|l|l|l|l|}
\hline Treatment & SUCRA & PrRank 1 & PrRank 2 \\
$(\%)$ & $(\%)$ & $\begin{array}{l}\text { PrRank 3 } \\
(\%)\end{array}$ & $\begin{array}{l}\text { Drug-related } \\
\text { adverse } \\
\text { events } \\
(n)\end{array}$ \\
\hline LLL, week 16-24 & 98.7 & 92.0 & 7.1 & 0.7 & 0 \\
\hline PRP, week 14-26 & 64.3 & 5.2 & 33.8 & 17.7 & 0 \\
\hline Finasteride 1 mg (male), week 48-52 & 62.5 & 1.2 & 8.3 & 27.2 & 15 \\
\hline Minoxidil 5\%, week 17-48 & 62.4 & 0.8 & 21.8 & 16.3 & $45^{*}$ \\
\hline Minoxidil 2\%, week 32-52 & 51.0 & 0.2 & 7.3 & 7.5 & 23 \\
\hline Dutasteride 0.5mg (male), week 26 & 32.9 & 1.2 & 8.3 & 7.5 & 8 \\
\hline Finasteride 1 mg (female), week 52 & 14.4 & 1.2 & 8.3 & 0.0 & 1 \\
\hline Placebo or sham & 13.4 & 0.0 & 0.0 & $27^{*}$ \\
\hline
\end{tabular}

SUCRA: surface under the cumulative ranking curve, PrRank: probability of best treatment and rank 1, 2 and 3 . "Minoxidil 5\% additionally reported 16 individual events of AEs and placebo or sham had 11 individual events 
Figure 1a. Working hypotheses of anti-androgens in AGA.

Without S-a reductase blocket

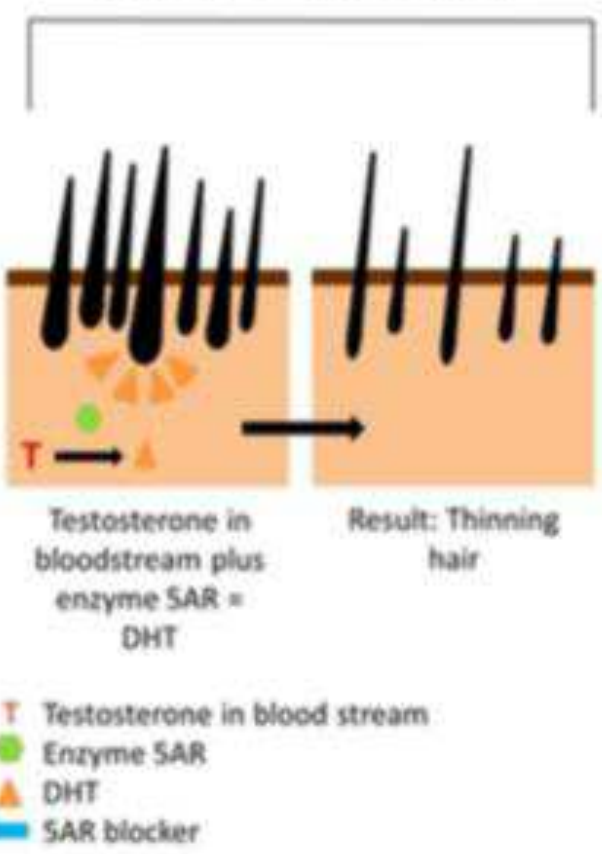

With 5-a reductase blocker
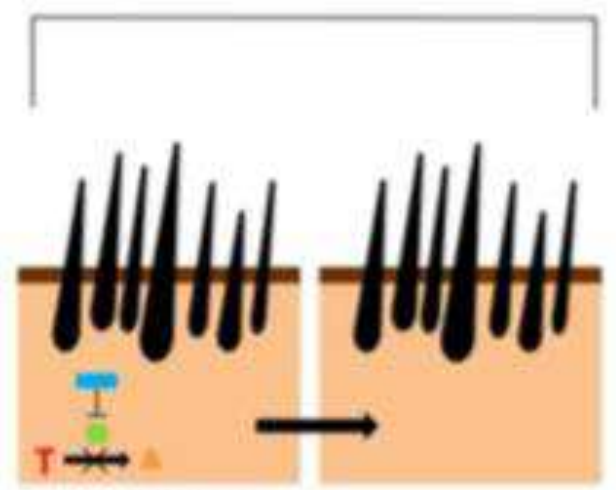

5Ak blockers inhibits enzyme SAR
Result: Normal hair 
Figure 1b. Working hypotheses of minoxidil in AGA.

Without vasodilatos

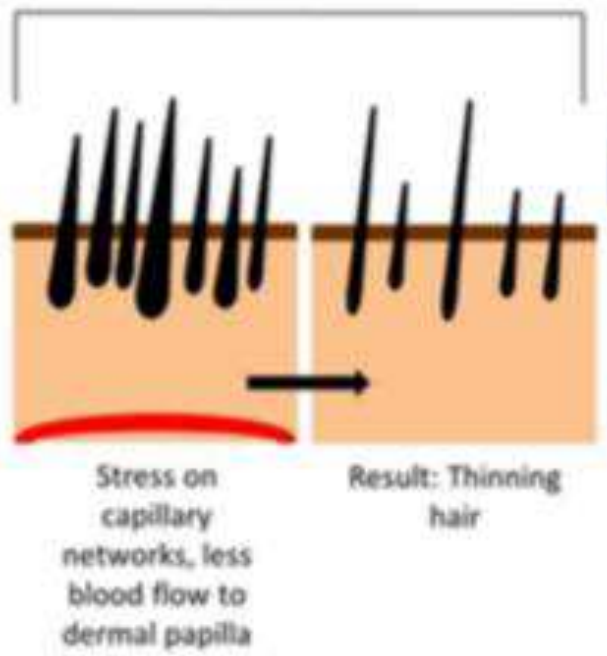

With vasodilator

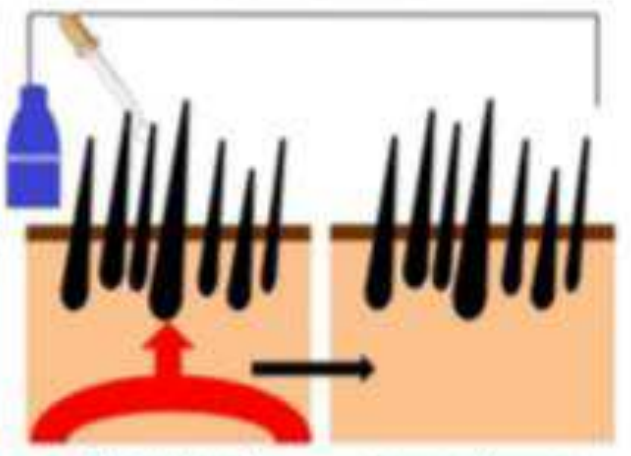

Blood vessel ditates, increases blood flow to the dermal papilla
Result: Normal hair 
Figure 1c. Working hypotheses of PRP in AGA.

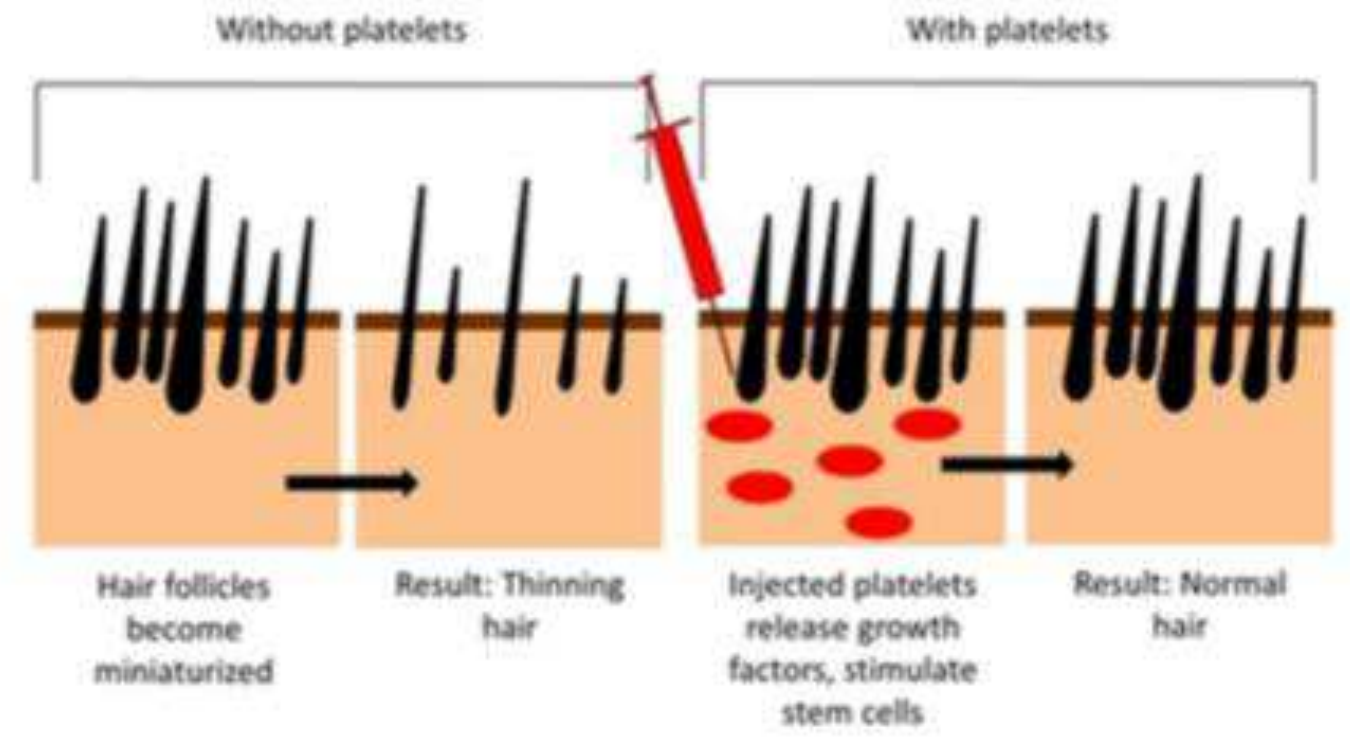


Figure 1d. Working hypotheses of LLLT in AGA.
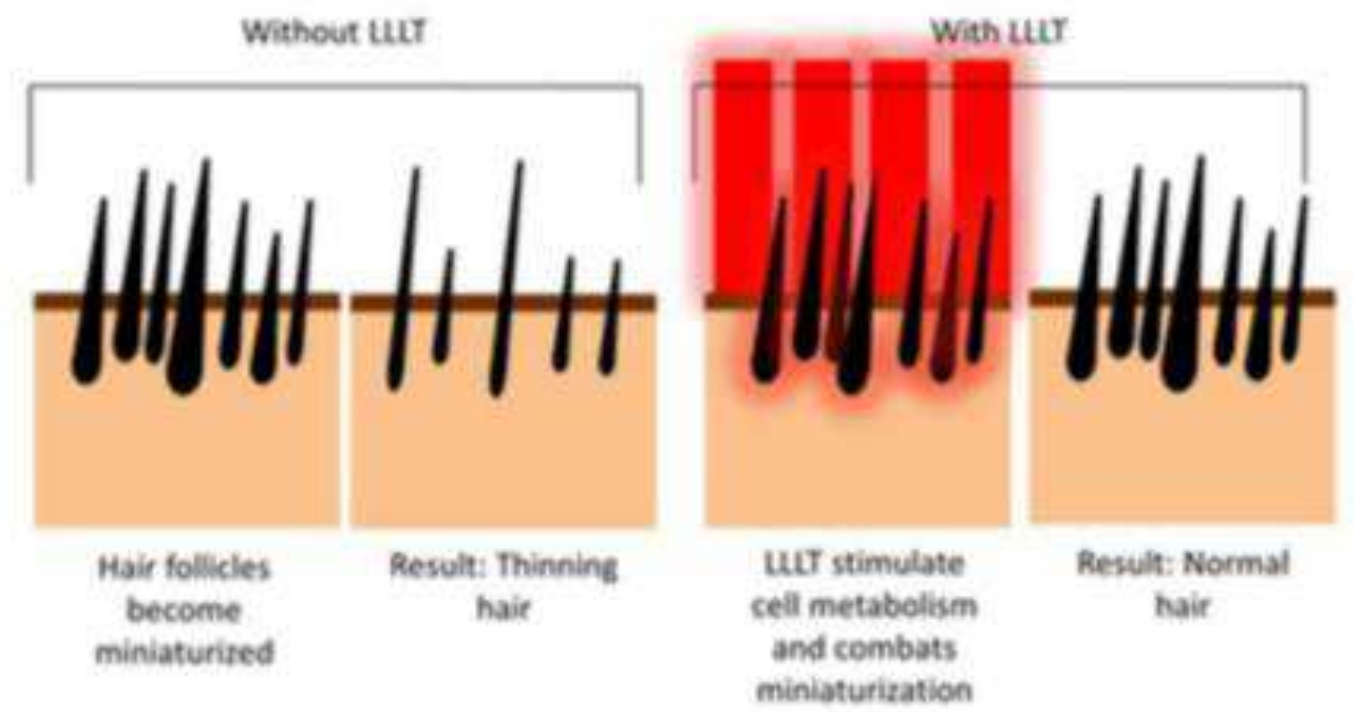
Figure 2. Summary of literature search for RCTs.

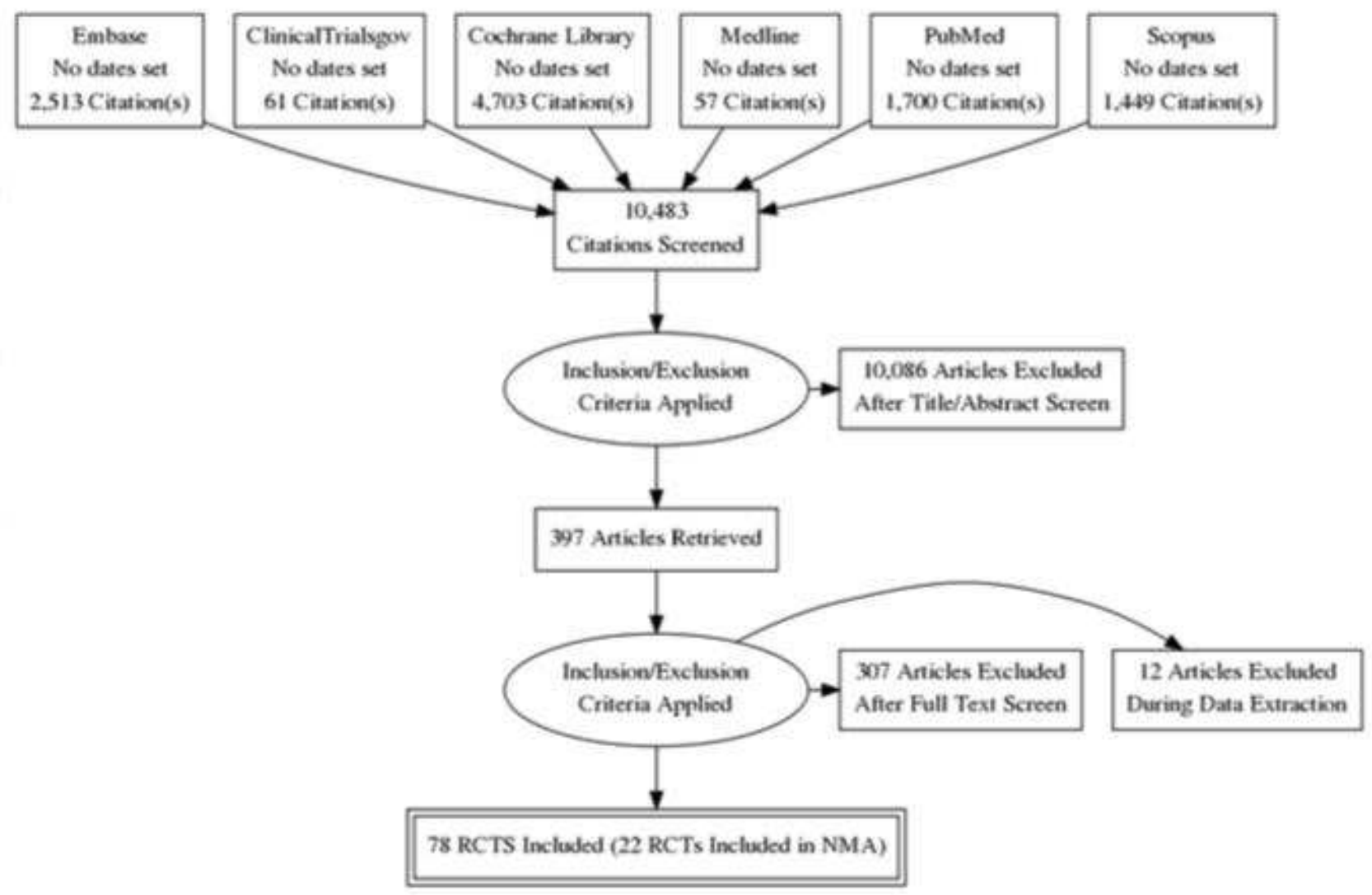


Figure 3. Network graph. The network graph shows the evidence network for all selected interventions. The size of an intervention's circle reflects the total number of participants for that intervention. Lines signify that interventions are connected through at least one study, with thicker lines indicating more connecting studies.

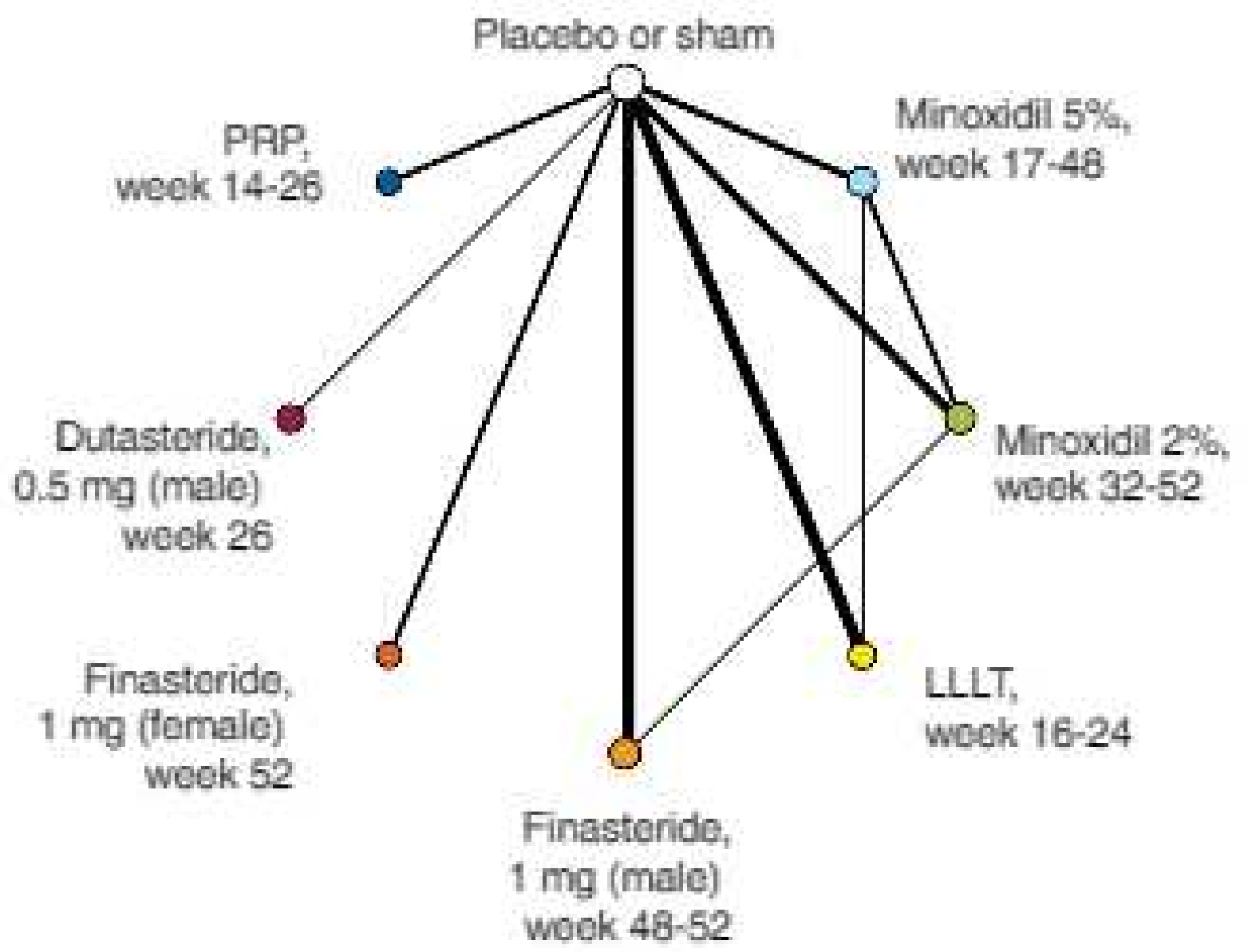


Figure 4. Bar plots for the ranking probabilities of competing non-surgical treatments for AGA. On the horizontal axis is the possible rank of each treatment (from best to worst according to the outcome). The size of each bar corresponds to the probability of each treatment to be at a specific rank.

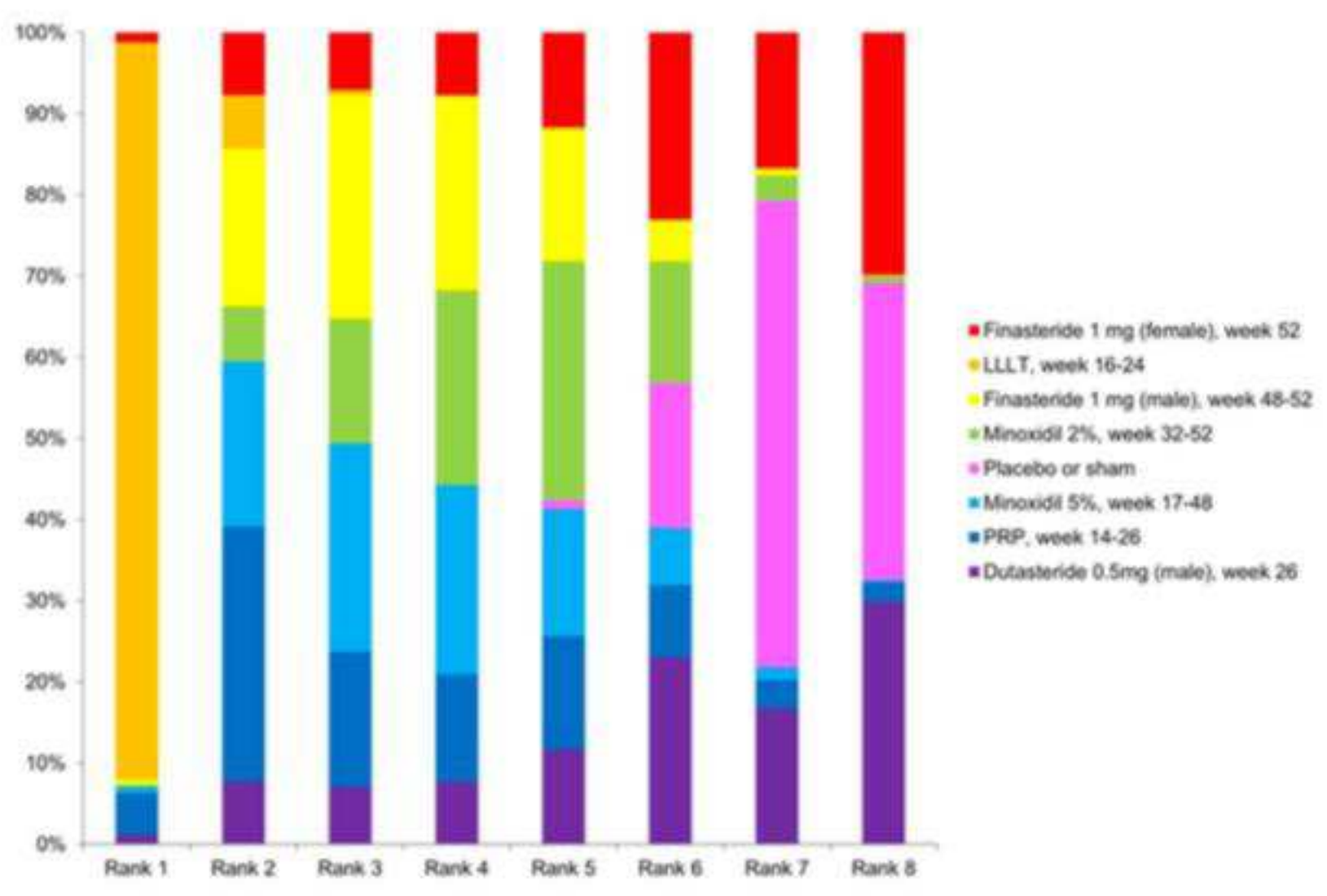

